\title{
CHALLENGES SHARED BY RESTORATIVE JUSTICE AND STRICT LIABILITY IN THE ABSENCE OF MENS REA
}

Golan Luzon*

Restorative justice programs have rapidly gained in popularity as a means of peaceful conflict resolution. At the same time, the programs raise concerns because in order to join, offenders assume responsibility for their acts, are automatically held culpable, and forfeit their rights under criminal law for representation, judicial review, and uniform sentencing, among others. Restorative justice shares this automatic culpability with strict liability, an older and proven legal tool that has had long experience convicting defendants without the need to prove mens rea. The present article explores the similarities between restorative justice programs and strict liability, with a view toward learning from the experience accumulated by strict liability in dealing with the absence of mens rea. To this end, the article discusses the distinction made under strict liability between incriminating and escalating responsibility, and explores the benefits that restorative justice programs can derive from such a distinction.

Keywords: strict liability, restorative justice, culpability, responsibility, mens rea

\section{INTRODUCTION}

In many countries, dissatisfaction and frustration with the formal justice system, as well as an interest in preserving and strengthening traditional

*Golan Luzon is a post-doctoral research fellow in the Faculty of Law at Bar-Ilan University, Israel. He holds doctoral degrees in law and philosophy from the Bar-Ilan University. His principal research interests are in criminal law, theories of punishment, the philosophy of law, and jurisprudence.

New Criminal Law Review, Vol. 19, Number 4, pps 577-59I. ISSN 1933-4192, electronic ISSN 1933-4206. (C) 2016 by The Regents of the University ofCalifornia. All rights reserved. Please direct all requests for permission to photocopy or reproduce article content through the University of California Press's Reprints and Permissions web page, http://www.ucpress.edu/ journals.php?p=reprints. DOI: I0.I525/nclr.2016.19.4.577. 
legal practices, have led to a search for alternative responses to crime and social disorder. ${ }^{1}$ This is how restorative justice programs have emerged, based on the belief that the parties to the offense should be actively involved in healing the rift created by the criminal incident. The programs have also been perceived as a means of encouraging peaceful conflict resolution, advocating tolerance, building mutual respect, and promoting community practices based on assuming responsibility. ${ }^{2}$

Assuming responsibility appears to be such a necessary and positive act that the problems it raises are often hidden from sight. One concern, which is the focus of the present article, is that the drive to refer many cases to restorative justice processes encourages defendants to assume responsibility for their acts without their culpability having been proven. Because of their desire to escape the consequences of their acts under criminal law, defendants assume responsibility for their actions, forfeiting the benefits of the protections granted to them under criminal law. As a result, restorative justice threatens to become a kind of strict liability mechanism, where defendants are convicted without their culpability having been proven.

Comparing restorative justice with strict liability is not straightforward. "Restorative justice" is a general label for alternative methods of dispute resolution in criminal law. ${ }^{3}$ Strict liability is a type of liability for which mens rea does not have to be proven in relation to one or more elements comprising the actus reus. Note that strict liability is not a degree of culpability; the defendant is automatically held culpable. Similarly, in the case of restorative justice, because participation in the process requires taking responsibility, there is no need for mens rea to be proven, and the defendant is automatically held culpable. Because of the similarity between the doctrine of strict criminal liability and the principles underlying restorative justice programs, and because in some criminal justice systems strict liability has been in existence for over a century, this article compares the two in an attempt to learn from the challenges they share.

Following this introduction, the article reviews the role of culpability in criminal law and its effect on perpetrators assuming responsibility for their

i. Heather Strang, Repair or Revenge: Victims and Restorative Justice (2002)

2. United Nations Office on Drugs and Crime, Handbook on Restorative Justice Programs, Criminal Justice Handbook Series (2006).

3. Alana Saulnier \& Diane Sivasubramaniam, Restorative Justice: Underlying Mechanisms and Future Directions, I8 NCLR 5IO-36 (2015). 
actions, with special emphasis on the importance of assuming responsibility in restorative justice programs, and on the concerns this raises. Next, it conceptualizes strict liability and compares it with restorative justice. Finally, a key distinction is made between incriminating and escalating strict liability, which may be profitably implemented in restorative justice. The article concludes with the practical suggestion that referrals to restorative justice programs should be made in four stages, with a correlation between the severity of the offense (and of punishment) and the stage at which the defendant is referred to the program.

\section{CULPABILITY AND RESPONSIBILITY IN CRIMINAL LAW}

In many legal systems, the presumption of innocence is a constitutional right of defendants in a criminal trial. ${ }^{4}$ If a person is presumed innocent until proven guilty, the burden of proof is on the prosecution, which must collect and present satisfactory and convincing evidence that the accused is culpable beyond a reasonable doubt. In most legal systems, to convict a defendant of a crime in accordance with due process, the prosecution must satisfy the requirements of the factual element of the crime (actus reus) and of a corresponding mental element (mens rea). For example, the Model Penal Code $(\mathrm{MPC})^{5}$ refers to mens rea as culpability. According to the MPC, every substantive element of every crime has a corresponding state of culpability (purpose, knowledge, recklessness, or negligence) ${ }^{6}$ that the prosecution must prove beyond a reasonable doubt. ${ }^{7}$

Criminal law ascribes overwhelming weight to the perpetrator's mental state or consciousness because it is an indication of the individual's will being carried out. It is the condition for imposing criminal liability on the perpetrator and for establishing his culpability. ${ }^{8}$ If the mental element is missing, it is not possible to impose criminal liability, and without criminal

4. For example, it is regarded as an international human right under the U.N. Universal Declaration of Human Rights, Art. II.

5. Model Penal Code and Commentaries (Official Draft and Revised Comments, 1985) [hereinafter MPC]. The MPC has served and continues to serve as a basis for the replacement of existing criminal codes in over two-thirds of the states.

6. MPC § 2.02, General Requirements of Culpability.

7. Paul H. Robinson, Criminal law: Case Studies \& Controversies (3d ed. 20i2); Paul H. Robinson, Teacher's Manual for Criminal Law: Case Studies and Controversies (2d ed. 2008).

8. See Andrew Ashworth, Principles of Criminal Law (2003). 
liability, it is not possible to convict the perpetrator. At the same time, the criminal process may deter perpetrators from assuming responsibility for their actions because defendants fear that it will lead to the imposition of criminal liability, conviction, and punishment. Defendants use various legal strategies to evade responsibility, often on the advice of their attorneys. These actions serve to intensify their lack of empathy toward the victim and the community, and create a sense of mutual alienation between them and society. This feeling is exacerbated throughout the legal process, and even more so during incarceration.

\section{RESPONSIBILITY IN RESTORATIVE JUSTICE}

In restorative justice, responsibility plays an important role, and accepting it (a sine qua non requirement for joining the process) ${ }^{9}$ involves confronting the consequences of the offense, including the effects of the conduct and the damages caused, and taking positive steps to repair the rift created by the offense. Assuming such responsibility is good for the victims, society, and the offenders because it combines responsibility for past actions with responsibility for present and future ones. The objective of this responsibility is to provide for the needs of the victim and of society, but also of the offender, in order to change him into a responsible agent, integrated within society.

Initially, responsibility deals with the damages caused, encourages mutual empathy, and relieves the sense of shame. In the second stage, it encourages personal change in the present, correcting the injurious conduct, coping with addictions, and improving personal skills. In the third stage, responsibility fosters future support for integrating the offender into the community. In restorative justice the process is far from complete with the conclusion of the restorative agreement among the parties (offender, victim, community), and it follows up on the offender meeting his obligations under the agreement as genuine proof of accepting responsibility. ${ }^{10}$

9. Acknowledging the basic facts of the crime and accepting responsibility is an important condition, stressed by international regulations on restorative justice. It can also be found in national laws, for example: New Zealand, Children, Young Persons, and Their Families Act § 259 (1989); Canada, Youth Criminal Justice Act § (e)(2)(20) (2003); Australia, Juvenile Justice Act $\S 22$ (1993); Belgium, Act of 22 June 2005 on Victim-Offender Mediation.

io. John Braithwaite, Crime, Shame and Reintegration (i989). 
Taking into account the responsibility of the offender for past actions, restorative justice emphasizes the circumstances that have led to his situation and recognizes retrospective responsibility, requiring us to explore the damages that the offenders themselves have sustained. In this aspect, restorative justice differs from criminal law, which gives priority to an internalist approach that examines responsibility only at the moment of action. ${ }^{11}$ Restorative justice processes adopt an externalist approach and ascribe substantial weight to the history that preceded the act. Research shows that a significant portion of offenders sustained severe trauma in their lives and regard themselves as victims. Past damages and the self-perception of victimhood on the part of offenders can contribute greatly to crime. ${ }^{12}$

Research shows that unresolved trauma tends to be reenacted if it is not properly treated, and it is liable to affect offenders, victims, and their families in future generations. ${ }^{13}$ Criminal law tends to respond to trauma with new trauma, such as incarceration. Under restorative justice, the trauma does not serve as an excuse for not accepting responsibility for past actions, but helps the parties understand the offender and helps the offender assume responsibility henceforth. Concern with history helps the offender accept future-oriented responsibility for his rehabilitation and for restoring the rift caused by his act.

\section{CONCERN WITH ASSUMING RESPONSIBILITY IN RESTORATIVE JUSTICE}

It is a common argument that restorative justice processes, such as victimoffender mediation, may help defendants escape the clutches of formal

il. John Martin Fischer \& Mark Ravizza, Responsibility and Control: An Essay on Moral Responsibility (1998). The internalist theory examines the psychological structure only at the precise moment of action, dividing time and addressing only the last slice. The externalist theory recognizes that freedom and responsibility depend on a psychological structure created by a causal history preceding that moment in time. The history includes causal characteristics found outside the agent, such as the education and socialization that shaped his or her values and beliefs.

i2. James Gilligan, Violence: Reflections on a National Epidemic (ig96) (arguing that all violence is an effort to achieve justice or to repair historic injustice, and that many criminal acts are a result of the offender's efforts to overcome the sense of victimhood).

i3. See Sandra Bloom, Creating Sanctuary: Toward the Evolution of Sane Societies (1997). 
criminal proceedings and strike an advantageous compromise. ${ }^{14}$ The concern is that by assuming responsibility for his actions, the accused waives the court hearing, joins one of restorative justice procedures, and avoids conviction and sentencing in court. ${ }^{15}$

But there is another side to the coin. Restorative justice processes are not compromises or mediation in the civil sense of the word, and may end in sentencing and punishment. Restorative interventions can be initiated at any stage of the criminal proceedings. In some countries restorative intervention is possible in parallel with prosecution and can be considered as part of the punishment. ${ }^{16}$ The concern is that in their eagerness to begin the process of restorative justice, defendants will rush to assume responsibility for their acts, forfeiting their legal rights, ${ }^{17}$ which are the basis for the requirement that the prosecution prove the culpability of the accused and therefore his criminal liability. Fearing prosecution, defendants might choose mediation even before they are aware of the evidence against them, the scope of defenses at their disposal, and before having analyzed the situation adequately. ${ }^{18}$ Even if restorative justice promotes fair results, fairness is not only a function of the outcome of the case; it also has to do with the proceedings that have led to this result. Defendants need the protection of criminal proceedings, including the right to legal representation and a judicial review that ensures that they do not assume responsibility under pressure. They also need the protection of evidentiary laws and of uniform sentencing. ${ }^{19}$

There is concern that in some cases the restorative justice process achieves the objective of punishment (a fine or community service) by blaming and punishing a person without his liability having been proven

I4. Jennifer Gerarda Brown, The Use of Mediation to Resolve Criminal Cases: A Procedural Critique, 43 EMORY L.J. I247 (1994).

i5. Robert B. Coates \& John Gehm, Victim Meets Offender: An Evaluation of Victim-Offender Reconciliation Programs 4 (I985) (surveyed offenders said that their primary goal in participating in VOM was to "avoid harsher punishment").

i6. Ivo Aertsen, R. Mackay, C. Pelikan, J. Willemsens, \& M. Wright, Rebuilding Community Connections: Mediation and Restorative Justice in Europe 24 (2004).

I7. Mark S. Umbreit, Mediation of Victim Offender Conflict, I988 J. Disp. Resol. 85, 88 (I988).

18. Richard Delgado, Goodbye to Hammurabi: Analyzing the Atavistic Appeal of Restorative Justice, 52 Stan. L. REV. 75I, 758-7I (2000).

19. Brown, supra note I4, at I247. 
according to the rules of criminal law. Consider the case of a person accused of assaulting his neighbor in the course of an argument, and suppose that the event was captured by security cameras. Before the person can be convicted in court, however, the prosecution must still prove that mens rea compatible with the assault was present. But to avoid the criminal proceeding, the defendant may assume responsibility for the assault in order to join a process of restorative justice, and pay monetary or equivalent compensation without his criminal liability having been proven.

Note that assuming responsibility in restorative justice is more than a manifestation of the usual process that takes place in criminal law. Unlike plea bargaining, for example, which promotes a settlement inside the court and under the watchful eye of the criminal code, restorative justice programs may be considered as diversion schemes that often include sanctions outside the court. ${ }^{20}$

Under the circumstances described above there is a similarity between the restorative justice process and the strict liability model in criminal law: in both cases it is possible to impose criminal liability on a person without proving his culpability. Strict liability has existed for many years, and it has become an integral part of criminal law despite the criticism that has been leveled against it. It is possible to examine the legal development of restorative justice by comparing it with strict liability, and discuss the implementation of restorative justice processes for many offenses by reference to strict liability offenses.

\section{STRICT CRIMINAL LIABILITY}

Strict liability is imposed on defendants in criminal cases without having to prove their culpability. ${ }^{21}$ To convict a defendant, most criminal codes require proof of a mental element compatible with the offense: purpose, knowledge, recklessness, or negligence. In the case of strict liability offenses, however, the defendant can be convicted and held liable for the offense without the need to prove any of the mental elements. ${ }^{22}$

20. Andrew Ashworth, Responsibilities, Rights and Restorative Justice, 42 BRIT. J. Criminology 578, 58I-82 (2002).

2I. In some legal systems, strict liability is the absence of proof of mens rea; in others, strict liability is the absence of mens rea.

22. Stephen J. Morse, Commentary: Reflections on Remorse, J. Am. Acad. Psychiatry \& L. 49 (2014). 
Over the years, strict liability was accepted constitutionally as a legitimate basis for the imposition of criminal liability for a variety of offenses. ${ }^{23}$ In the United States, the Supreme Court has ruled consistently that strict liability is not contrary to the U.S. Constitution because it is consistent with the principles of criminal law. ${ }^{24}$ Similar recognition was granted by state law in the United States, ${ }^{25}$ England, ${ }^{26}$ and in most legal systems worldwide. $^{27}$

Despite its exceptional nature, the doctrine of strict liability was accepted in criminal law for several reasons. ${ }^{28}$ First, its procedural efficiency is complemented by economic efficiency. Legislatures have assumed that if the prosecution is required to prove mens rea or negligence, it is difficult to impose criminal liability for offenses where the evidence concerning the existence of mens rea is entirely in the possession of the defendant.

Strict liability has educational benefits as well, because it uses the law to convey a message to the public and because of the deterrence it creates. ${ }^{29}$ Therefore, strict liability helps create a high standard of public behavior and caution. The expectation is that in certain areas the public will show

23. G. R. Sullivan, Strict Liability for Criminal Offences in England and Wales Following Incorporation into English Law of the European Convention on Human Right, Appraising strict liability, in Appraising Strict Liability, Oxford Monographs on Criminal Law and Justice (Andrew Simester ed., 2005).

24. For example: Smith v. California, 36I U.S. I47, 80 S.Ct. 215, 4 L.Ed.2d 205 (1959); Lambert v. California, 355 U.S. 225, 78 S.Ct. 240, 2 L.Ed.2d 228 (1957); Texaco Inc. v. Short, 454 U.S. 516, I02 S.Ct. 78I, 70 L.Ed.2d 738 (1982); Carter v. United States, 530 U.S. 255 , 120 S.Ct. 2159, I47 L.Ed.2d 203 (2000).

25. For example: State v. Stepniewski, Ios Wis.2d 26I, 3I4 N.W.2d 26I, 3I4 N.W.2d 98 (1982); State v. Mcdowell, 3I2 N.W.2d 30I (N.D. 198I); State v. Campbell, 536 P.2d I05 (Alaska 1975); Kimoktoak v. State, 584 P.2d 25 (Alaska 1978); Hentzner v. State, 613 P.2d 82I (Alaska 1980); State v. Brown, 389 So.2d 48 (La. 1980).

26. For example: G., (2008) U.K.H.L. 37, (2009) A.C. 92; Barnfather v. Islington London Borough Council, (2003) E.W.H.C. $4 \mathrm{I} 8$ (Admin), (2003) I W.L.R 2318 (2003), E.L. R. 263 .

27. For example: Australia: Kennedy, (198I) V.R. 565; White, (1979) 23 A.L.R. 439; Harris, (1999) T.A.S.S.C. 53 D.C.R. 416; New Zealand: Department of Health v. Multichem Laboratories Ltd., (I987) I N.Z.L.R. 334; Canada: Kanda, (2008) O.J. No. 80, 2008 O.N.C.A. 22, 22.

28. Nicola Lacey, Celia Wells, \& Oliver Quick, Reconstructing Criminal LAW (2006).

29. About models of social control that focus on the ability of the law to shape people's behavior, see Franklin Zimring, Gordon Hawkins, \& James Vorenberg, Deterrence: The Legal Threat in Crime Control (1973). 
increased responsibility and behave more cautiously, which will prevent harm to people and property. ${ }^{30}$

\section{THE SHARED CHALLENGES OF RESTORATIVE JUSTICE AND STRICT CRIMINAL LIABILITY}

Over the years, the doctrine of strict liability elicited many criticisms, the most important being that it violates a fundamental principle of criminal law whereby no liability should be imposed without proof of culpability ( ullum crimen sine culpa). According to the same principle, there can be no crime without criminal intent. Strict liability offenses, in which criminal liability is imposed without proof of culpability, contradict the nature of criminal law. The principle of criminal law is violated both when we impose liability on the defendant without proof of culpability and when the defendant assumes responsibility in order to participate in a restorative justice process, which in practice allows taking punitive action against him without proving his culpability.

The justification of the doctrine of strict liability was based primarily on utilitarian reasons, aimed at promoting efficient regulation of various routine and essential areas of activity having to do with public policy. In the case of strict liability, the efficiency is first and foremost economic, by diverting procedural costs from society to the defendant. ${ }^{31}$ Similarly, it is possible to justify the process of restorative justice, wherein the defendant assumes responsibility for his action, for utilitarian reasons. Many studies have found that restorative justice processes were more effective than traditional criminal proceedings in preventing recidivism and future harm. It is further assumed that the restorative justice model serves the victim's needs more efficiently than does the traditional criminal process by redressing the wrongs and damages caused by the crime. ${ }^{32}$

30. Mordechai Kremnizer, Justified Deviations from the Requirement of "Mens Rea," I3(I) Bar-Ilan Law Studies iog (I996).

3I. Admittedly, the legal presumption that a person intends the ordinary consequences of his voluntary acts often has the effect of shifting the burden of proof when it comes to purpose or knowledge. But in many cases this is impossible (see Sandstrom v. Montana, 442 U.S. 5IO (1979)), and the prosecution has no choice but to prove mens rea beyond a reasonable doubt, even if it is difficult to do so. In this sense, strict liability helps the prosecution by shifting the burden of proof entirely to the defendant.

32. Carrie J. Menkel-Meadow, Restorative Justice: What is it and does it work?, 3 Ann. Rev. L. \& Soc. SCI. I6I (2007). Gerry Johnstone \& Daniel W. Van Ness, Restorative Process, 
Nevertheless, because the doctrine of strict liability and restorative justice processes affect both conviction and punishment in criminal law, they cannot rely exclusively on utilitarian reasons. ${ }^{33}$ Indeed, classical criticism against strict liability in criminal law comes from retributionists. ${ }^{34}$ The theory of retribution is part of deontological moral teaching, according to which the imposition of liability on the defendant not only serves a utilitarian end, but it is a moral duty to retaliate in a manner appropriate to the severity of the crime. ${ }^{35}$ The degree of culpability and punishment must suit the gravity of the offense in order to balance the moral equation. Despite its utility, strict criminal liability might lead to punishing the innocent; it is therefore not fair according to a retrospective theory of retribution. ${ }^{36}$

\section{DISTINGUISHING BETWEEN INCRIMINATING AND ESCALATING STRICT LIABILITY}

To justify the strict liability doctrine within criminal law, it is necessary to impose substantial restrictions on its use. Therefore, strict liability offenses were presented as light ones that require relatively mild punishment. Thus, even if the principle whereby no criminal responsibility can be imposed without culpability is violated, the harm is not severe if the offenses are minor and the punishment not harsh. In practice, however, strict liability offenses are more complex and not restricted exclusively to light criminal offenses. In principle, if the defendant committed a strict liability offense, it is possible to impose liability on him and convict him without the prosecution having to prove his culpability.

But it is necessary to distinguish between incriminating and escalating strict liability. For incriminating strict liability, culpability is not required

Outcomes Stakeholders, in Handbook of Restorative Justice 209 (G. Johnstone \& D.W. Van Ness eds., 2007). Mark S. Umbreit, Victim Meets Offender: The Impact of Restorative Justice and Mediation (1994). Mark S. Umbreit \& Robert B. Coates, Victim Offender Mediation: An Evolving Evidence Based Practice, in Handbook of Restorative Justice: A Global Perspective 52 (D. Sullivan \& L. Tifft eds., 2006).

33. George P. Fletcher, The Grammar of Criminal Law: American, ComparATIVE, AND INTERNATIONAL I98-99 (2007).

34. Michael King, Arie Freiberg, Becky Batagol, \& Ross Hyams, Non-AdVERSARIAL Justice 44-45 (2009).

35. John Rawls, Two Concepts of Rules, 64PHil. Rev. 3, 5 (1955).

36. Hadar Dancig-Rosenberg \& Tali Gal, Restorative Criminal Justice, 34 Cardozo L. ReV. 23r3 (2013). 
with regard to each essential element of the offense. For escalating strict liability, culpability is required with regard to at least one essential element but not for an additional element that creates a more severe offense. ${ }^{37}$ In the case of incriminating strict liability, we convict the defendant because of strict liability imposed on him without having proven his culpability. In the case of escalating strict liability, we convict the defendant of a more severe offense than the offense for which he was proven culpable. For example, unlawfully taking property in excess of a specified amount is grand larceny, whereas unlawfully taking property of less than that amount is petty larceny. Therefore, if the defendant is found culpable of petty larceny, but the amount stolen turns out to place the crime in the category of grand larceny, there is no need for the prosecution to prove mens rea for the more serious offense. ${ }^{38}$

Analysis of the instances of strict liability reveals that the range of offenses for which the law allows the imposition of strict liability is broader than it appears at first. The argument that criminal liability is imposed without the need to prove mens rea only for minor offenses that involve light punishment is inaccurate, ${ }^{39}$ and a broad survey shows that legislatures allow imposing strict liability to convict defendants also of serious crimes and to impose harsh penalties. ${ }^{40}$

How are serious offenses of strict liability reconciled with the requirements of retribution? ${ }^{41}$ In the case of incriminating strict liability offenses, a problem can arise because a person is convicted and punished without criminal intent having been proven in his actions. But the relatively light punishment for these offenses offsets and softens the harm to retribution.

37. Lawrence Crocker, Justice in Criminal Liability: Decriminalizing Harmless Attempts, 53 Онго Sт L.J. I057, 1066 n.24 (1992). Seе MPC § 223.I.

38. Kenneth W. Simons, When Is Strict Criminal Liability Just?, 87 J. Crim. L. \& Criminology I075 (1997). This argument is based on Simons's discrimination between the two types of strict liability, but the terms used in his article have been changed here to "incriminating" and "escalating" because they more accurately reflect the nature of these two types of liability.

39. Larry Alexander, Reconsidering the Relationship Among Voluntary Acts: Strict Liability, and Negligence in Criminal Law, 7(2) Soc. PHIL. \& Pol'y 84 (1990).

40. Jeremy Horder, Strict Liability, Statutory Construction and the Spirit of Liberty, II8 LAW Q. REV. 458 (2002).

4I. Michael Moore, The Moral Worth of Retribution, in Responsibility, Character, and the Emotions: New Essays in Moral Psychology 179 (Ferdinand Schoeman ed., I988). 
In the case of escalating strict liability offenses, proving culpability is required for at least one substantive element. Therefore, the culpability that must be proven in court can justify, from the point of view of retribution, the conviction and punishment of the defendant. ${ }^{42}$

\section{DISTINGUISHING BETWEEN INCRIMINATING AND ESCALATING RESTORATIVE JUSTICE PROGRAMS}

Are restorative justice programs offered in the case of offenses involving a high degree of culpability? History shows that most restorative justice programs are designed for minor offenses or juvenile offenders caught in their first criminal act, and they offer a range of effective alternatives for youths at risk. Because of their educational value, these programs are especially useful for diverting the cases away from the court and for providing alternatives to punishment, and especially incarceration, of the youths. But programs have often been developed for adult offenders as well, and in recent years an increasing number of countries allow more severe offenders to participate in restorative justice processes. For example, in 2004, the Australian legislation made explicit provisions for implementation of restorative justice programs, for young and adult offenders alike, for crimes of domestic violence. ${ }^{43}$ Similarly, restorative justice programs have been developed in many countries for adult offenders and serious offenses. ${ }^{44}$

How is restorative justice reconciled with the demand for retribution ${ }^{45}$ in the case of serious offenses? Similarly to the doctrine of strict liability, it is possible to distinguish between incriminating strict liability and escalating strict liability within the restorative justice process as well. Concern with encouraging defendants to assume responsibility without criminal intent

42. About the moral justification of retribution, see details in Leo Zaibert, Punishment And Retribution (2006).

43. Crimes (Restorative Justice) Act 2004 (ACT) $\S$ I6(I), (2).

44. Mark S. Umbreit \& Marilyn P. Armour, Restorative Justice Dialogue: An Essential Guide for Research and Practice (20iI). For restorative justice schemes in the United Kingdom, see Joanna Shapland, Restorative Justice in Practice: Evaluating What Works for Victims and Offenders (20II). For restorative justice schemes in Canada, see James S. Latimer, The Effectiveness of Restorative Justice Practices: A Meta-Analysis, 85(2) PrIsOn J. 127 (2005).

45. Michael Wenzel, Tyler G. Okimoto, Norman T. Feather, \& Michael J. Platow, Retributive and Restorative Justice, 32 Law \& Hum. BeHav. 375 (2008). 
having been proven is not equal in all cases. Cases are referred to the restorative justice programs at different stages of the criminal proceeding. For minor offenses, the referral is usually made by the police, even before indictment, and the defendant assumes responsibility at an early stage of the proceeding, forfeiting the defenses available to him. Assuming responsibility is what allows him to participate in the process, but it is also what incriminates him. The balance is restored by the fact that the offenses are light and that offenders are referred to the restorative justice processes at an early stage, so that the restorative agreement does not impose severe sanctions on the defendant. At the next level, the referral to the restorative process is made by the prosecution, after filing the indictment but before the trial. The offenses in question are still relatively minor, and even if the defendant assumes responsibility in order to avoid going to trial, the sanctions that are part of the restorative agreement are relatively light.

In later stages, it is the court that refers cases to restorative justice, before sentencing or as part of the punishment and as an alternative to incarceration (or to a portion of it). In these cases the offenses are serious and punishment is commensurate. But assuming responsibility as part of the process of restorative justice at these stages is not incriminating, because the culpability of the defendant has already been proven and linked to some degree of criminal intent at the conviction stage. Therefore, a successful restorative justice process can only mitigate the punishment or serve as a substitute for it. In some sense, assuming responsibility after the criminal intent has been proven only escalates the severity of the sentence or the length of incarceration.

The point at which the case is referred to the restorative justice programs de facto determines the extent to which the defendant's assumption of responsibility incriminates the offender or escalates the offense. The restorative justice program in effect in Nova Scotia, Canada (Nova Scotia Restorative Justice) serves as a good example. ${ }^{46}$ From the inception of this program, its declared objective was to become a comprehensive alternative to the criminal justice system and to realize the principles of restorative justice for young and adult offenders alike, for their victims, their families, and their communities. The program was the focus of a comprehensive

46. Bruce Archibald \& Jennifer Llewellyn, The Challenges of Institutionalizing Comprehensive Restorative Justice: Theory and Practice in Nova Scotia, 29 DALhousie L.J. 297 (2006). 
study that examines the development of restorative justice practice in Canada. Discretion in referring cases to NSRJ depends on the level (severity) of the offense. Level 4 offenses are the most severe ones. These offenses can be referred to the program only at the stages of punishment (sentencing) and imprisonment (by detention officers). This applies, for example, to offenders convicted of rape or murder. Level 3 offenders can be referred to the program after indictment and before trial, or after the trial, at the sentencing stage. The offenses are serious ones, such as fraud and theft of large amounts (over $\$ 20,000$ ), robbery, sex offenses, aggravated assault, criminal negligence, reckless driving resulting in death, manslaughter, and domestic violence. In other words, restorative justice does not divert offenses at levels of severity 3 and 4 from the formal legal process, but is supplemental to the sentencing process; therefore, it does not incriminate the accused but escalates the degree of punishment.

Restorative justice programs used to divert cases from the formal legal process or to serve as alternatives to formal court proceedings begin at level 2 offenses. These offenses constitute the largest category, and can be referred to the restorative justice process at each of the four entry points. This means that the police and the district attorney can refer the bulk of criminal offenses to the restorative justice program instead of prosecuting them, but punishment, as in cases of strict criminal liability, is relatively light. Offenses of severity level I are misdemeanors, such as purchasing alcohol illegally, minor property offenses, disorderly conduct, and assault without damage or bodily harm; in these cases, the referral does incriminate the accused, but the punishment is mild.

The Nova Scotia model, based on the severity of offenses, shows how a rating can be implemented in restorative justice practice. According to this model, the lighter the offense, the earlier it is referred to the restorative justice program; in these cases the referral incriminates the accused, but punishment is light. The more severe the offense, the later it is referred to the restorative justice program; referral, however, does not incriminate the accused but rather increases his punishment, although on occasion it may lighten it.

\section{CONCLUSION AND PRACTICAL RECOMMENDATION}

Classic offenses of strict criminal liability are considered relatively light (such as public welfare offenses), where the conduct of the defendant raises 
a presumption of culpability. The defendant is responsible for his act and is punished for it without proof of mens rea. In due course, these offenses have been adapted to the principles of criminal law through clear legislation that allowed increasing the severity of the offense for certain crimes and imposing responsibility on defendants without proving their culpability in a criminal trial.

Analysis of the instances of strict liability in criminal law shows that the range of offenses for which the law allows the imposition of strict liability is broader than it seems. We distinguish between relatively light, "criminalizing" offenses and "escalating" ones, which can be more serious. In offenses in which assuming responsibility incriminates, the balance is restored by the lesser degree of culpability and lighter punishment. In the case of more serious offenses, where the assumption of responsibility is escalating, the level of culpability is high and punishment often severe. In the case of such an offense, the balance lies in the fact that the source of culpability in mens rea is already present in one of the other elements of the offense. Thus, a regime of strict liability is consistent with the retributive approach because the correlation between the degree of culpability and the severity of punishment is retained at all levels.

Similarly, we should distinguish between assuming incriminating and escalating responsibility in restorative justice programs. Referral to restorative justice programs is made in four stages, with a correlation between the severity of the offense (and of punishment) and the stage at which the defendant is referred to the program. In early-stage referrals, before indictment, the offense is relatively light, and even if assuming responsibility incriminates the defendant, the punishment is quite light. If the defendant is referred to the restorative program later in the process, assuming responsibility has a less incriminating and a more escalating effect on punishment. Thus, even if the punishment is severe, it may be mitigated following a restorative process. Similarly to strict criminal liability, the balance between the severity of punishment, the degree of culpability, and the function of responsibility allows the processes of restorative justice to be fair and reasonable, and at the same time consistent with retributive theory. 